\title{
Største reform i nyere tid af Udenrigstjenesten
}

Af Martin Lidegaard

I løbet af sommeren er omlægningen af Udenrigstjenesten trådt i kraft. Reformen indebærer en justering af Danmarks diplomatiske tilstedeværelse i mere end 25 lande. Omlægningen er en følge af de globale udviklingstendenser og ønsket om stærkere støtte til danske borgere og dansk erhvervsliv.

Fire danske ambassadører, der skal varetage Danmarks interesser i Nigeria, Fillippinerne, Columbia og Myanmar, har netop startet deres arbejde. Nogle af ambassaderne er allerede åbnet, og resten åbner i løbet af de kommende måneder. Med åbningerne får Danmark nu direkte adgang til over 300 millioner nye forbrugere i en række vækstlande. Det er lande med vækst, potentiale, muligheder, udvikling og udfordringer. Lande med stigende politisk indflydelse. Lande, der står over for at udvikle deres samfund - en udvikling vi skal og kan påvirke i samarbejde med landenes myndigheder.
Åbningerne er led i den største reform og modernisering af den danske udenrigstjeneste i nyere tid. Reformen, som regeringen besluttede i januar i år, indebærer en justering af Udenrigsministeriets - og dermed også Danmarks - tilstedeværelse i mere end 25 lande.

Med reformen besluttede regeringen at åbne nye ambassader i en række lande og styrke vores tilstedeværelse generelt i flere lande. For at finde midlerne til det, var vi imidlertid også nødt til at lave en ganske omfattende omprioritering, hvor vi over sommeren har lukket nogle repræsentationer helt - ikke mindst i Europa - og skåret ned på størrelsen $\mathrm{i}$ andre.

\section{Nye tiltag og omprioriteringer}

Med reformen har regeringen fokuseret på, hvad der var behov for at ændre for bedst muligt at varetage Danmarks interesser i udlandet. Hovedspørgsmålet var: Hvad skal vi gøre mere af og hvor kan vi skære ned for at skabe plads til det, vi gerne vil gøre mere af? Overskrifterne for reformen er:

Martin Lidegaard har været Danmarks udenrigsminister siden 3. Februar 2014. Forinden var han klima- og energiminister. Han var folketingsmedlem for Det Radikale Venstre i perioden $2001-$ 2007. Han har arbejdet som kommunikationsrådgiver, formand for CONCITO og informationschef og vicegeneralsekretær for Mellemfolkeligt Samvirke. 
ministeriet arbejder med, er målsætningen grundlæggende klar, nemlig at skabe resultater af værdi for Danmark; for dansk økonomi og beskæftigelse, for danske borgere og virksomheder.

Og det gør vi selvfølgelig i den verden, som omgiver os. Det er en verden i hastig forandring. Over de kommende tyve år vil verdensøkonomien blive fordoblet. Klodens befolkning vil nærme sig ni milliarder mennesker. Den globale middelklasse vil vokse med tre milliarder mennesker, og millioner vil blive hevet ud af ekstrem fattigdom. Samtidig vil vi opleve en fortsat forskydning af de globale økonomiske og politiske magtstrukturer, et øget pres på klodens naturressourcer og de fortsatte udfordringer fra de globale klimaforandringer.

Alt dette betyder, at vi de senere år har set en voldsom politisk og økonomisk magtforskydning væk fra Vesten og over mod nye vækstlande og regioner. Med den økonomiske magt følger også øget politisk indflydelse. De nye lande engagerer sig mere og mere aktivt i udenrigspolitiske og udenrigsøkonomiske emner. Nye formelle og mere uformelle fora, som fx G20-møderne og World Economic Forum, er på kort tid blevet vigtigere fora for internationale drøftelser og beslutninger, ikke bare på det økonomiske område. Styrkeforholdene ændrer sig, og det påvirker selvsagt Danmarks handlerum og muligheder. Vi skal se nøje på, hvordan vi fremmer danske interesser og mærkesager, men vi skal også hele tiden have de rette rammer og strukturer på plads til at kunne gøre dette.

\section{Bundlinjen}

Ud over de globale udviklingstendenser oplever vi også, at der i diplomatiet er øget fokus på 'bundlinjen', og at det i stigende grad er og skal være en kerneopgave, at Udenrigstjenesten bidrager til at skabe vækst og beskæftigelse i Danmark. Det er et indsatsområde, vi selv har prioriteret højt, men samtidig et område, hvor der sta- dig er store og voksende forventninger til Udenrigsministeriet.

Vi skal kunne gribe mulighederne og begrænse udfordringerne, der følger af de globale forandringer. Et meget vigtigt element er, at Udenrigstjenesten skal støtte danske borgere og dansk erhvervsliv. Danmark skal fastholde et stærkt internationalt engagement og styrke vores eksport og tiltrække flere investeringer til Danmark for at skabe job. Det kræver en ændret tilstedeværelse. Derfor udruller vi nu den største modernisering af Udenrigstjenesten i nyere tid. Med den første samlede strategi for myndighedssamarbejde, eksport og økonomisk diplomati nogensinde er vi samtidig klar med 40 nye initiativer for 155 mio. kr. De nye tiltag skal styrke dansk erhvervsliv på nye markeder og i udviklingslandene for at bidrage til en bæredygtig vækst og fremme danske løsninger på de store globale udfordringer inden for fx energi, sundhed, uddannelse, vand og miljø.

Et andet vigtigt element er, at vi skal ind og påvirke myndighederne i de nye vækstlande. Alle lande, men særligt vækstøkonomierne, står over for en række afgørende strategiske samfundsvalg de kommende år. De valg skal Danmark påvirke og sætte danske fingeraftryk på i en retning, der understøtter Danmarks interesser og grundlæggende værdier.

Det er ikke ligegyldigt, hvilken type vækst det bliver, og vi skal være med til at påvirke samfundsudformning, standarder og regulering i den nye verdensorden og dermed bidrage til, at væksten bliver socialt og miljømæssigt bæredygtig. Samtidig skal vi være bevidste om, at den 'politiske økonomi' i mange af vækstøkonomierne er meget anderledes end den, vi kender fra Vesten.

Udenrigstjenesten må tilpasse sig for også fremover at skabe mest mulig værdi for vores kunder og samarbejdspartnere i og uden for Danmark. Det gør vi ved at være en åben og samarbejdende udenrigstjeneste og gennem tæt dialog og samspil med vores brugere. Og ved at sikre en opti- 


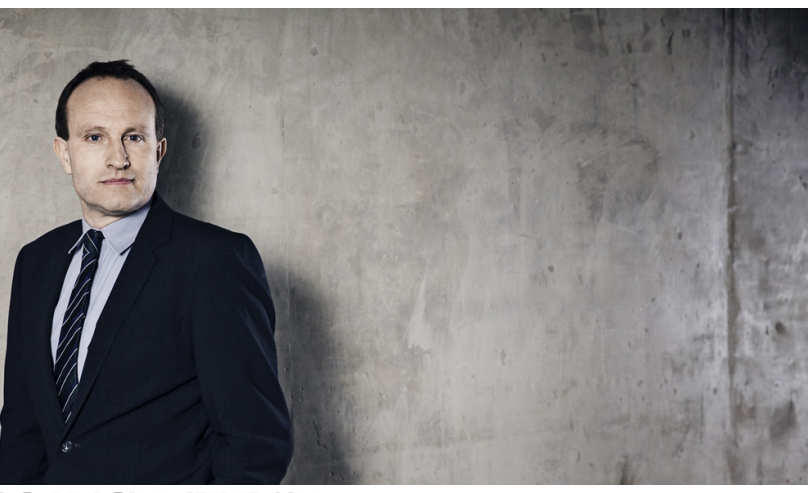

Som alle andre er Udenrigsministeriet løbende nødt til at se på, hvordan Udenrigsministeriet som organisation prioriterer og er organiseret.

mal udnyttelse af vores globale netværk af repræsentationer.

De globale udviklingstendenser og ændrede rammebetingelser, som jeg har beskrevet, har nødvendiggjort den reform af Danmarks repræsentationsstruktur, som nu træder i kraft. En reform, der nødvendigvis må gennemføres inden for de økonomiske rammebetingelser, der gælder for Udenrigsministeriets og resten af statens virksomhed. Udenrigsministeriet flytter regelmæssigt rundt på vores ressourcer. Men reformen og moderniseringen af repræsentationsstrukturen går videre og sikrer, at vi i løbet af 2014 og fremover får opdateret vores globale tilstedeværelse, så vi også fremover er de rigtige steder, med den rette tyngde og den mest relevante profil.

\section{Længe undervejs}

Reformen af repræsentationsstrukturen har sådan set været ganske længe undervejs. Som alle andre er Udenrigsministeriet løbende nødt til at se på, hvordan Udenrigsministeriet som organisation prioriterer og er organiseret.

EU-formandskabet i 2012 krævede mange ressourcer, og da det var vel gennemført, blev det besluttet at give Udenrigsministeriet et 'servicetjek' for at svare på spørgsmål som: Hvordan anvender vi vores ressourcer mest effektivt? Og hvordan prioriterer vi vores opgaver bedst muligt?
Ud over dette mere interne fokus stod det allerede tidligt klart, at der også fremover ville være behov for løbende justering i repræsentationsstrukturen ude.

I den første del af processen koncentrerede Udenrigsministeriet sig om ressourcerne i København. Man så bl.a. på, hvor ministeriet kunne styrke arbejdet og strømline det. Det Københavns-fokuserede arbejde blev gjort færdigt før sommeren 2013. Derefter vendte ministeriet blikket mod at reformere repræsentationsstrukturen. I september 2013 startede vi de interne overvejelser med inddragelse af medarbejdere både ude og hjemme.

Samtidig besluttede ministeriet at involvere en række centrale brugere og samarbejdspartnere i diskussionen om, hvilke principper der skulle gælde for reformen af repræsentationsstrukturen - den såkaldte Refleksionsgruppe. Refleksionsgruppen bestod af repræsentanter fra universitetsmiljøet, erhvervs- og fagorganisationerne, NGO'ere etc.

Det er første gang, at regeringen og Udenrigsministeriet har involveret eksterne aktører i overvejelserne om ambassadejusteringer, men det var en metode, som gav et rigtigt godt ind- og samspil i forhold til ministeriets interne proces.

Refleksionsgruppen skulle ikke drøfte konkrete åbninger og lukninger, men levere indspil til den mere principielle drøf- 
telse om de globale tendenser og udviklingstræk af betydning for prioritering af udenrigstjenestens opgaver, de nye krav og forventninger til repræsentationernes opgavevaretagelse, samt alternative tilstedeværelsesformer. Refleksionsgruppen var et godt afsæt for en bred dialog om de udfordringer, som Udenrigsministeriets repræsentationsnetværk står overfor.

Den 28. oktober 2013 afsluttedes samarbejdet med Refleksionsgruppen med en stor konference med over 100 deltagere og en god dags diskussion af fremtidens udenrigstjeneste.

Hele processen med Refleksionsgruppen gav en række vigtige input til den konkrete udmøntning af reformen. Der er stærke og tungtvejende interesser på spil, når man drøfter Danmarks repræsentationsstruktur. Drøftelserne i Refleksionsgruppen afslørede dog en bred enighed om de bærende principper for den reform, som efterfølgende blev besluttet af regeringen i januar 2014 . Men dialogen med vores samarbejdspartnere og kunder fortsætter, også efter reformen er ført ud i livet. Kun i tæt samarbejde med alle vores partnere $i$ ind- og udlandet kan vi sikre, at udenrigstjenesten forbliver så relevant som muligt, effektiv og merværdiskabende.

\section{Besparelser}

Jeg vil også gerne komme ind på de finansielle implikationer af reformen. Formålet med reformen er først og fremmest at sørge for, at Danmarks globale tilstedeværelse er opdateret og tidssvarende. Men det er klart, at det også er for at tage hensyn til de økonomiske rammer, som Udenrigstjenesten arbejder indenfor. Ligesom alle andre skal Udenrigsministeriet spare de kommende år. Nogle af besparelserne håndteres med den effektiviseringsplan, Udenrigsministeriet har gennemført over de sidste par år, men yderligere besparelser er nødvendige. Reformen af ambassadestrukturen skønnes at bidrage med reduktion af Udenrigsministeriets årlige drifts- og lønomkostninger med knap
10 mio. kr., når ændringerne i repræsentationsstrukturen, det vil sige såvel lukninger og nedprioriteringer som åbninger og styrkelser, er fuldt ud gennemført.

Tre ud af de fire nye ambassader bliver placeret sammen med andre landes ambassader, så der opnås besparelser på bl.a. sikkerhed. I Myanmar er der tale om et nordisk ambassadesamarbejde, i Nigeria et dansk/ schweizisk og i Colombia etableres ambassaden hos Nederlandene.

Nigeria, Filippinerne og Colombia er de tre markeder uden aktuel dansk diplomatisk repræsentation, hvor den største markedsudvidelse ventes at ske frem mod 2020. Dansk erhvervsliv har længe efterspurgt en permanent tilstedeværelse her - og der er en betydelig efterspørgsel efter borgerserviceydelser i disse lande. Det er vigtige grunde til, at vi åbner netop disse steder. Men det er også lande med betydelig regional politisk vægt, hvor Danmark dermed også får en større regional platform.

Nigeria er en helt central aktør i regionen og i Afrika, både politisk, økonomisk og sikkerhedsmæssigt, samt når det gælder bekæmpelsen af grænseoverskridende kriminalitet til lands og til søs.

Colombia har med forbedrede regionale relationer øget sin politiske vægt på kontinentet, er blevet vigtig i det regionale samarbejde med bl.a. Chile og Peru og er på vej til at blive Sydamerikas tredjestørste økonomi. Indenrigspolitisk er der sket fremskridt med fredsforhandlinger med FARC, og den nye flerpartshandelsaftale mellem EU og Colombia, som trådte i kraft den 1 . august 2013, vil yderligere lette adgangen til markedet for bl.a. danske firmaer.

Filippinerne er en toneangivende aktør i ASEAN både politisk og i den regionale sikkerhedsarkitektur i Sydøstasien.

Og Myanmar er efter årtier med konflikt, militærstyre og isolation på vej mod demokrati. Danmark har i mange år støttet en demokratisk udvikling og vil fortsætte hermed. Målet er at fremme en demokratiserings- 
og reformproces, en fredelig udvikling med bedre levevilkår for især de etniske minoriteter samt bidrage til fremme af en bæredygtig, ansvarlig og inklusiv økonomisk vækst.

\section{EU og Europa}

EU er, og vil fortsat være, den vigtigste politiske og økonomiske platform for varetagelsen af danske interesser. Det er afgørende for Danmark at være solidt repræsenteret tæt på de vigtigste beslutningscentre, og så har EU også med den Fælles Udenrigstjeneste fået et afsæt til at spille en større og mere samlet rolle globalt. Arktis er i stigende grad i fokus både sikkerhedspolitisk, økonomisk og ift. bæredygtig udvikling, og det er en prioritet for Danmark at påvirke udviklingen i området i en bæredygtig retning.

Selvom vi også må lukke flere steder, end vi åbner, og er nødt til at skære ned en række steder, så betyder det langtfra, at vi ikke fortsat vil følge og samarbejde med disse lande eller fremme danske interesser. Det kommer dog til at ske på en anden og mindre intens måde. Desuden vil en række af opgaverne de pågældende steder fortsat blive prioriteret og varetaget af andre af vores repræsentationer.

Hovedvægten af lukninger ligger i Europa. Europa er og vil fortsat være vores vigtigste handelsområde og den vigtigste vej til politisk indflydelse. Derfor er det heller ikke en let beslutning at lukke flere repræsentationer i Europa. Der er tale om repræsentationer, som gennem årene har tjent Danmark godt, og som har været med til at opbygge vores omdømme og troværdighed i de enkelte lande og på den europapolitiske scene. Der er stadig mange danske interesser i de pågældende lande - både politiske, kulturelle og økonomiske. Der vil også fremover være danske statsborgere i disse lande, og der vil være danske virksomheder, som vil ind på disse markeder. Vi vil da også fortsætte og læg- ge vægt på det tætte politiske samarbejde, som vi har i dag. Men vi må finde andre måder at gøre det på, fx gennem hyppigere politiske kontakter og besøg, eller øget brug af vores netværk af honorære konsuler. Og så vil regeringen som nævnt opprioritere EU-indsatsen ved at styrke bemandingen på EU-repræsentationen og i EU's tungeste beslutningscentre.

\section{Merværdi for Danmark}

Som et lille land med en aktiv udenrigspolitik og en åben økonomi skal vi hele tiden holde fokus på den politiske og økonomiske bundlinje. Hvor skaber vi størst merværdi med vores repræsentationer? Danmarks repræsentationsstruktur følger vores politiske og økonomiske interesser. Sådan vil det altid være. Vores reform og modernisering af Danmarks tilstedeværelse rundt omkring i verden har et helt klart endemål: at vi til hver en tid har de bedst mulige forudsætninger for at kunne varetage Danmarks og danskernes interesser.

Der er i dag meget fokus på den nye økonomiske verdensorden, på vækstmarkeder og på økonomisk diplomati og myndighedssamarbejde. Det afspejler sig også i vores reform. Men tag ikke fejl - det traditionelle diplomati er lige så vigtigt i dag, som det var i går. Vi vil fortsat levere en solid indsats, når det gælder sikkerhedspolitik, europapolitik, udviklingspolitik, handelspolitik, borgerservice og public diplomacy. Det er kerneområder, og de er også fortsat af højeste prioritet.

Repræsentationsnetværket er til for os alle sammen - borgere, virksomheder og samarbejdspartnere i ind- og udland. Med den ambitiøse modernisering af Udenrigstjenesten og vores ambassader sikrer regeringen, at Danmark er klar til en ny verden, hvor det skaber mest værdi for Danmark - politisk - og når det gælder vækst og beskæftigelse. 